Available online at http://jurnal.goretanpena.com/index.php/JSSR

\title{
ANALISIS WSM DAN WP DALAM MENENTUKAN PUPUK TERBAIK DENGAN PENDEKATAN WSM-SCORE DAN VECTOR
}

\author{
Asyahri Hadi Nasyuha ${ }^{1}$, Suardi Yakub ${ }^{2}$, Widarti Rista Maya ${ }^{3}$ \\ Yohanni Syahra ${ }^{4}$, Saniman $^{5}$ \\ STMIK Triguna Dharma,Medan \\ e-mail: ${ }^{1}$ asyahrihadi@gmail.com
}

\begin{abstract}
Fertilizer is a material that is given to the soil or plants to meet the nutritional needs of the plant. Fertilization needs to be done rationally according to plant needs. In the supply of fertilizer, farmers have difficulty in determining the best fertilizer for their crops, making it difficult to choose which fertilizers are good for their crops. In determining the best fertilizer, a decision support system can be used as an alternative to help someone make decisions more effectively and efficiently by utilizing certain data and models. To solve the existing problems, it is necessary to conduct research in decision making using the Weighted Sum Model (WSM) and Weight Product (WP) Methods which can produce decisions based on the best fertilizer criteria that will be purchased by customers. The Weighted Sum Model (WSM) method is one of the simplest and easiest methods to understand its application, this method is also part of the MCDM (Multi-Criteria Decision Making) method in evaluating the value of each alternative. The Weight Product (WP) method is a method using multiplication to relate the attribute rating, where the rating of each attribute must be ranked with the attribute weight in question. From the results of the implementation of this system, it can be concluded that using the Weighted Sum Model and Weight Product method can help customers in the decision-making process for choosing the best fertilizer to use on their plants.
\end{abstract}

Keywords: Decision Support System, WSM and WP, Bayes, Firtilizer

\begin{abstract}
Abstrak: Pupuk merupakan bahan yang diberikan ke tanah atau tanaman untuk mencukupi kebutuhan nutrisi tanaman(Novita \& Sari, 2015). Pemupukan perlu dilakukan secara rasional sesuai dengan kebutuhan tanaman. Dalam persediaan pupuk, petani mengalami kesulitan dalam menentukan pupuk terbaik untuk tanamannya sehingga mempersulit dalam pemilihan pupuk apa yang baik untuk tanamannya. Dalam menentukan pupuk terbaik Sistem pendukung keputusan dapat digunakan sebagai alternatif dalam membantu seseorang dalam mengambil keputusan dengan lebih efektif dan efisien dengan memanfaatkan data dan model tertentu. Untuk menyelesaikan permasalahan yang ada, maka perlu dilakukan penelitian dalam pengambilan keputusan dengan menggunakan Metode Weighted Sum Model (WSM) dan Weight Product (WP) yang dapat menghasilkan keputusan berdasarkan kriteria-kriteria pupuk terbaik yang akan dibeli oleh pelanggan. Metode Weighted Sum Model (WSM) merupakan salah satu metode yang paling sederhana dan mudah dipahami penerapannya, metode ini juga merupakan bagian dalam metode MCDM (Multi-Criteria Decision Making) dalam mengevaluasi nilai pada setiap alternatif. Metode Weight Product (WP) merupakan metode dengan menggunakan perkalian untuk menghubungkan rating atribut, dimana rating setiap atribut harus dipangkatkan dengan bobot atribut yang bersangkutan. Dari hasil implementasi sistem ini, dapat disimpulkan bahwa dengan menggunakan metode Weighted Sum Model dan Weight Product dapat membantu pelanggan dalam proses pengambilan keputusan pemilihan pupuk terbaik yang akan digunakan pada tanamannya.

Kata kunci: Sistem Pendukung Keputusan, Wsm dan Wp, Pupuk.
\end{abstract}


Available online at http://jurnal.goretanpena.com/index.php/JSSR

\section{PENDAHULUAN}

Pupuk merupakan bahan yang diberikan ke tanah atau tanaman untuk mencukupi kebutuhan nutrisi tanaman. Pemupukan perlu dilakukan secara rasional sesuai dengan kebutuhan tanaman, kemampuan tanah menyediakan unsur-unsur hara, sifat-sifat tanah dan pengolahan oleh petani(Widia \& A., 2017). The Best Firtilizer merupakan pupuk yang digunakan pada jenis tanaman apapun, pupuk ini bisa berbentuk padat maupun cair. The Best Firtilizer juga bisa menghasilkan tanaman menjadi lebih baik lagi, karena nutrisi yang diberikan ketanaman sudah mencukupi. Pupuk banyak mengandung zat - zat yang sangat dibutuhkan tanaman untuk memberikan nutrisi pada tanaman.

Pemupukan pada tanaman dapat dilakukan dengan menggunakan pupuk organik dan pupuk anorganik. Pupuk organik adalah pupuk yang dihasilkan dari perubahan atau penguraian bagianbagian tanaman dan binatang, misalnya pupuk kandang, pupuk hijau, kompos, bungkil, guani, tepung tulang dan sebagainya.

Sedangkan pupuk anorganik merupakan pupuk yang dibuat dari pabrik bahannya berasal dari bahan anorganik dan dibentuk dengan proses kimia. Pupuk menjadi bahan utama pada tanaman guna untuk memberi nutrisi pada tanaman. Pemilihan pupuk dapat dilihat dari jenis tanamannya dan nutrisi apa yang dibutuhkan tanaman tersebut, maka dengan itu untuk menentukan pupuk apa yang baik pada tanaman tersebut diterapkan sebuah sistem pendukung keputusan.

\section{METODE}

Sistem terdiri dari beberapa komponen yang saling berhubungan dan bekerja sama untuk mencapai tujuan, dengan cara menerima masukan serta menghasilkan keluaran dalam proses transformasi dan organisasi(Luh Made
Yulyantari, 2018)(Nasyuha, 2019a). Sistem terdiri dari Input, Process, dan Output. Input merupakan kegiatan memasukan data untuk diproses dalam sistem, Process merupakan sistem yang mengelolah data menjadi informasi, Output merupakan hasil akhir dari informasi yang dilakukan dalam sistem. Sedangkan menurut pressman, sistem berbasis komputer adalah serangkaian atau tatanan elemen-elemen untuk mencapai tujuan yang ditentukan sebelumnya melalui pemrosesan informasi. Untuk mencapai tujuan tersebut, ada beberapa elemen sistem yang digunakan, yaitu:

1. Perangkat lunak (Software)

Berupa pemrograman komputer, struktur data, serta dokumen yang berhubungan dan berfungsi untuk memengaruhi metode logis, prosedur, dan kontrol yang dibutuhkan.

2. Perangkat keras (Hardware)

Berupa perangkat elektronik yang memeberikan kemampuan perhitungan dan perangkat elektromekanik (misalnya sensor, rotor, pompa) yang memberikan fungsi dunia eksternal.

3. Manusia (Brainware)

Manusia adalah pemakai dan operator perangkat keras dan lunak.

4. Basis data

Merupakan kumpulan informasi besar dan terorganisasi, yang di akses melalui perangkat lunak.

5. Dokumentasi

Merupakan hasil dari observasi dengan cara manual, formulir, serta informasi deskriptif lainnya yang menggambarkan penggunaan dan atau pengoperasian sistem.

6. Prosedur

Prosedur adalah langkah-langkah yang menentukan penggunaan khusus dari masing-masing elemen sistem atau konteks prosedural di tempat sistem berbeda. 
Available online at http://jurnal.goretanpena.com/index.php/JSSR

Sistem Pendukung Keputusan atau Decision Support System (DSS) merupakan sistem informasi interaktif yang menyediakan informasi, pemodelan, dan pemanipulasian data(Sugiartawan et al., 2018). Sistem itu digunakan untuk membantu pengambilan keputusan dalam situasi yang semi terstruktur dan situasi yang tidak terstruktur, dimana tak seorang pun tahu secara pasti bagaimana keputusan saharusnya dibuat(Zulfandi et al., 2018). Sistem Pendukung Keputusan (SPK) merupakan suatu sistem berbasis komputer yang interaktif, yang membantu pengambil keputusan memanfaatkan data dan model untuk menyelesaikan masalahmasalah yang tak terstruktur dan semi terstruktur(Panjaitan et al., 2019). Pada dasarnya SPK dirancang untuk mendukung seluruh tahap pengambilan keputusan mulai dari mengidentifikasi masalah, memilih data yang relevan, menentukan pendekatan yang digunakan dalam proses pengambilan keputusan, sampai mengevaluasi pemilihan alternatif(Nasyuha, 2019b). Jadi kesimpulan dari sistem pendukung keputusan ini adalah sistem yang berbasis komputer yang mengumpulkan berbagai informasi dari beberapa sumber dan mampu memecahkan masalah dari beberapa alternatif, sehingga dapat memunculkan penyelesaian baru.

Menurut Simon, proses pengambilan keputusan meliputi empat fase, yaitu:

1. Fase inteligensi

Fase ini merupakan peroses pengambilan keputusan dengan menentukan masalah, mengidentifikasi gejala-gejalanya, menentukan keleluasaannya, dan mengidentifikasinya secara eksplisit.

2. Fase Desain

Fase ini merupakan proses mengidentifikasi dan mengeksplorasi berbagai solusi.

3. Fase Pilihan

Fase ini merupakan tindakan mengambil keputusan di antara alternatif solusi. Fase ini juga termasuk fase yang membuat keputusan nyata dan komitmen untuk menjalani tindakan tertentu.

4. Fase Implementasi

Pada fase ini merupakan fase di mana membuat pekerjaan alternatif yang dipilih dan memantau seberapa baik solusi bekerja serta menjalankan rangkaian yang dipilih dalam tahapan membuat dan memilih aksi tersebut

Metode Weighted Sum Model (WSM) adalah model umum, telah digunakan untuk aplikasi yang berbeda seperti robotika, processor, dan lain-lain. Ini adalah metode yang sering digunakan pada permasalahan dimensi tunggal(Sianturi, 2019)(Handoko et al., 2017). Jika terdapat $m$ alternatif dan $n$ kriteria, maka alternatif terbaik. Adapun algoritma penyelsaian dari metode ini adalah(Friskila Parhusip, Dedy Hartama, 2018):

1. Langkah I : Mengidentifikasi terlebih dahulu dari kriteria dan alternatif yang digunakan dalam penyelesaian masalah.

2. Langkah II : menghitung nilai $W S M$ Score. Adapun rumus yang digunakan metode ini yaitu :

$$
A_{j}^{W S M-s c o r e}=\sum_{j=1}^{n} W_{j} X^{i j}
$$

Dimana :

$\mathrm{n}=$ jumlah kriteria

$W_{j}=$ bobot dari setiap kriteria

$X_{i j}=$ nilai matrik $\mathrm{x}$

3. Langkah III : Melakukan perangkingan.

Metode Weighted Product merupakan metode dengan menggunakan perkalian untuk menghubungkan rating atribut, dimana rating setiap atribut harus dipangkatkan dengan bobot atribut yang bersangkutan(Amalia et al., 2019). Metode Weighted Product (WP) merupakan salah satu metode penyelesaian yang ditawarkan untuk menyelesaikan masalah Multi Atribute 
Available online at http://jurnal.goretanpena.com/index.php/JSSR

Decission Making (MADM)(Fajarianto et al., 2017). Metode Weighted Product (WP) mirip dengan metode Weighted Sum (WS), hanya saja Weighted Product, terdapat perkalian dalam perhitungan matematikanya(Mulawarman et al., 2015). Metode Weighted Product juga disebut analisis berdimensi karena struktur matematikanya menghilangkan satuan ukuran.

Tahapan-tahapan metode Weight Product dalam pengambilan keputusan adalah(Fajarianto et al., 2017):

1. Menentukan kriteria-kriteria terlebih dahulu.

Menormalisasikan setiap nilai alternatif dengan perbaikan bobot dengan rumus :

$$
W_{j}=\frac{w_{j}}{\sum w_{j}}
$$

Dimana :

$W_{j}=$ Bobot atribut

$\sum W_{j}=$ Penjumlahan bobot atribut

2. Menghitung nilai bobot preferensi pada setiap alternatif dengan variabel $\mathrm{W}$ adalah pangkat bernilai positif untuk atribut keuntungan dan bernilai negatif untuk atribut biaya. Preferensi untuk alternatif $S i$ diberikan sebagai berikut :

$$
S_{i}=\prod_{j=1}^{n} X_{i j} W_{j}
$$

Dimana :

$S_{i}=$ Preferensi alternatif dianologikan sebagai vector $\mathrm{S}$

$X_{i j} \quad=$ Nilai kriteria

$W_{j} \quad=$ Bobot Kriteria/subkriteria

$\mathrm{i}=$ Alternatif

$\mathrm{j}=$ Kriteria

3. Melakukan perangkingan yang diperoleh dari nilai terbesar yang dipilih sebagai alternatif terbaik.

Dengan Rumus

Dimana :

$$
V_{i}=\frac{s i}{\prod_{j=1}^{n}(X j *) w j}
$$

$\mathrm{V}=$ Preferensi alternatif

dianalogikan sebagai vektor $\mathrm{V}$

$\mathrm{X}=$ Nilai Kriteria

$$
\begin{aligned}
\mathrm{W} & =\text { Bobot atribut } \\
\mathrm{i} & =\text { Alternatif } \\
\mathrm{j} & =\text { Kriteria } \\
\mathrm{n} & =\text { Banyaknya kriteria }
\end{aligned}
$$

\section{Metodologi Penelitian}

Metode Penelitian merupakan proses pengumpulan dan analisis data yang dilakukan secara sistematis dan logis untuk mencapai tujuan tertentu. Di dalam sebuah penelitian terdapat beberapa tahapan yaitu sebagai berikut:

1. Kegiatan observasi dalam penelitian ini dilakukan dengan tinjauan langsung ke UD. Bona Tani yang beralamat di Jl. Besar BP Mandoge Kec. Hatonduhan Simalungun. Di UD. Bona Tani tersebut dilakukan analisis masalah serta kebutuhan yang diperlukan dengan cara mengamati langsung pemilihan pupuk yang dilakukan oleh pelanggan yang datang ke tempat tersebut. Sehingga dapat disimpulkan masalah apa yang terjadi dan solusi apa yang dibutuhkan untuk mengatasi masalah tersebut.

2. Teknik pengumpulan data yang selanjutnya adalah wawancara. Wawancara merupakan kegiatan tanya jawab yang dilakukan dengan narasumber. Teknik wawancara ini dilakukan guna mengetahui informasi yang berkaitan tentang pemilihan pupuk yang baik untuk tanaman.

Dari hasil observasi dan wawancara didapatkan data seperti di bawah ini:

Metodologi penelitian merupakan penjelasan langkah-langkah penyelesaian dari suatu masalah dalam perancangan sistem pendukung keputusan dalam memilih back-end programmer dengan menggunakan metode Weighted Sum Model (WSM) dan Weight Product (WP). Hal ini dilakukan untuk meningkatkan penilaian yang efektif dan efisien untuk menentukan pupuk terbaik. 
Available online at http://jurnal.goretanpena.com/index.php/JSSR

\section{Algoritma Sistem}

Algoritma sistem merupakan penjelasan langkah-langkah penyelesaian dari suatu masalah dalam perancangan sistem pendukung keputusan dalam memilih back-end programmer dengan menggunakan metode Weighted Sum Model (WSM) dan Weight Product (WP). Hal ini dilakukan untuk meningkatkan penilaian yang efektif dan efisien untuk menentukan pupuk terbaik.

Berikut ini adalah flowchart dari metode Weighted Sum Model (WSM) sebagai berikut:

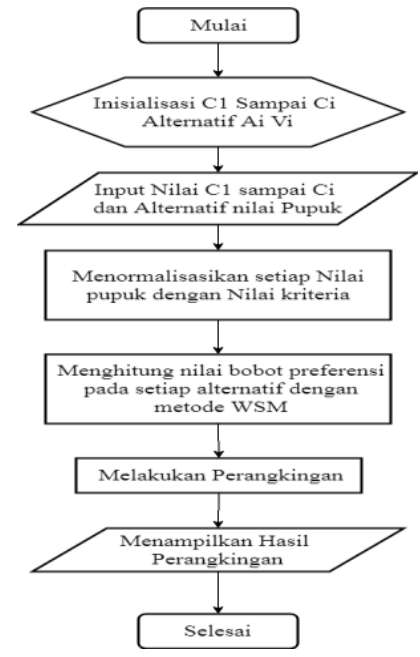

Gambar 1. Flowchart dari metode Weighted Sum Model

Berikut ini adalah flowchart dari metode Weight Product (WP) sebagai berikut:

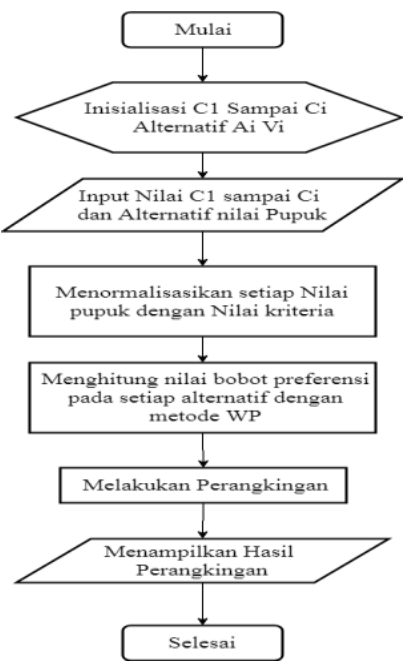

Gambar 2. Flowchart dari metode Weight Product

Dalam penelitian ini terlebih dahulu didefenisikan kriteria-kriteria yang akan dijadikan tolak ukur penyelesaian masalah dan menentukan tingkat kepentingan dari setiap kriteria. Berikut tabel kriteria yang digunakan:

Tabel 2. Tabel Bobot Kriteria

\begin{tabular}{|c|c|c|}
\hline Kode Kriteria & Nama Kriteria & Bobot \\
\hline K1 & Harga & 5 \\
\hline K2 & Kualitas & 4 \\
\hline K3 & Mudah Didapat & 4 \\
\hline K4 & Bentuk Pupuk & 3 \\
\hline
\end{tabular}

Untuk melakukan analisis perhitungan dari setiap alternatif dan kriteria yang diberikan maka dibutuhkan skala pembobotan dari setiap kriteria, berikut skala yang digunakan:

Tabel 3. Skala Pembobotan

\begin{tabular}{|c|c|c|}
\hline Kriteria & Skala & Bobot \\
\hline \multirow[t]{5}{*}{ Harga } & $0-100.000$ & 1 \\
\hline & $101.000-200.000$ & 2 \\
\hline & $201.000-300.000$ & 3 \\
\hline & $301.000-400.000$ & 4 \\
\hline & $\geq 500.000$ & 5 \\
\hline \multirow[t]{5}{*}{ Kualitas } & Sangat Baik & 5 \\
\hline & Baik & 4 \\
\hline & Cukup Baik & 3 \\
\hline & Kurang Baik & 2 \\
\hline & Sangat Tidak Baik & 1 \\
\hline \multirow[t]{3}{*}{ Mudah Didapat } & $\mathrm{Ya}$ & 5 \\
\hline & Kadang-Kadang & 3 \\
\hline & Tidak & 1 \\
\hline \multirow[t]{2}{*}{ Bentuk Pupuk } & Padat & 5 \\
\hline & Cair & 1 \\
\hline
\end{tabular}

Kemudian data alternatif yang diusulkan dilakukan konversi nilai untuk mendapatkan nilai yang akan dihitung dengan metode yang digunakan, berikut data konversi penilaian pupuk yang digunakan: 
Available online at http://jurnal.goretanpena.com/index.php/JSSR

2. Menghitung nilai WSM-Score dengan rumus :

Tabel 4. Konversi Data Pupuk

\begin{tabular}{|c|c|c|c|c|}
\hline \multirow{2}{*}{$\begin{array}{c}\text { Kode } \\
\text { Alternatif }\end{array}$} & $\begin{array}{c}\text { Harga } \\
\text { (C1) }\end{array}$ & $\begin{array}{c}\text { Kualitas } \\
(\mathrm{C} 2)\end{array}$ & $\begin{array}{c}\text { Mudah } \\
\text { Didapat } \\
\text { (C3) }\end{array}$ & $\begin{array}{c}\text { Bentuk } \\
\text { Pupuk } \\
\text { (C4) }\end{array}$ \\
\hline A1 & 4 & 4 & 5 & 5 \\
\hline A2 & 5 & 5 & 5 & 5 \\
\hline A3 & 2 & 4 & 3 & 5 \\
\hline A4 & 2 & 3 & 3 & 5 \\
\hline A5 & 1 & 4 & 3 & 1 \\
\hline A6 & 3 & 4 & 5 & 5 \\
\hline A7 & 4 & 4 & 5 & 5 \\
\hline
\end{tabular}

\section{HASIL DAN PEMBAHASAN}

Berdasarkan tabel bobot awal yang telah ditentukan dari setiap kriteria, Pengambil keputusan memberikan bobot preferensi adalah $\mathrm{w}=[5,4,4,3]$ dimana $\mathrm{W}=(\mathrm{W} 1, \mathrm{~W} 2, \mathrm{~W} 3, \mathrm{~W} 4)$.

1. Perbaikan Nilai Bobot

Perbaikan nilai bobot awal akan Kode diperbaiki dengan cara :

$$
W_{j}=\frac{w j}{\sum w j}
$$

Untuk Harga :

$\mathrm{W} 1=\frac{5}{5+4+4+9}=\frac{5}{16}=0,3125$

Untuk Kualitas :

$\mathrm{W} 2=\frac{4}{5+4+4+9}=\frac{4}{16}=0,25$

Untuk Mudah didapat :

$\mathrm{W} 3=\frac{4}{5+4+4+9}=\frac{4}{16}=0,25$

Untuk Bentuk pupuk :

$\mathrm{W} 4=\frac{3}{5+4+4+9}=\frac{3}{16}=0,1875$

Dari proses pembobotan di atas di dapatkanlah bobot akhir sebagai berikut :

Tabel 5. Perubahan Nilai Bobot $\left(\sum W j=\right.$

$$
\text { 1) }
$$

\begin{tabular}{|c|c|c|}
\hline No & Nama Kriteria & Bobot \\
\hline 1 & Harga & 0,3125 \\
\hline 2 & Kualitas & 0,25 \\
\hline 3 & Mudah Didapat & 0,25 \\
\hline 4 & Bentuk Pupuk & 0,1875 \\
\hline & Jumlah & 1 \\
\hline
\end{tabular}

$A_{j}^{W S M-\text { score }}=\sum_{j=1}^{n} W_{j} X^{i j}$

$\mathrm{A} 1=(0,3125 * 4)+(0,25 * 4)+(0,25 * 5)+$

$(0,1875 * 5)=4,44$

$\mathrm{A} 2=(0,3125 * 5)+(0,25 * 5)+(0,25 * 5)+$

$(0,1875 * 5)=5$

$\mathrm{A} 3=(0,3125 * 2)+(0,25 * 4)+(0,25 * 3)+$

$(0,1875 * 5)=3,31$

$\mathrm{A} 4=(0,3125 * 2)+(0,25 * 3)+(0,25 * 3)+$

$(0,1875 * 5)=3,06$

$\mathrm{A} 5=(0,3125 * 1)+(0,25 * 4)+(0,25 * 3)+$

$\left(0,1875^{*} 1\right)=2,25$

$\mathrm{A} 6=(0,3125 * 3)+(0,25 * 4)+(0,25 * 5)+$

$(0,1875 * 5)=4,13$

$\mathrm{A} 7=(0,3125 * 4)+(0,25 * 4)+(0,25 * 5)+$ $(0,1875 * 5)=4,44$

Dari hasil perhitungan yang dilakukan berdasarkan metode Weighted Sum Model (WSM) didapat nilai dari alternatif sebagai berikut :

Tabel 6. Perangkingan Berdasarkan Nilai Preferensi

\begin{tabular}{c|c|c|c|}
\hline $\begin{array}{c}\text { Kode } \\
\text { Alternatif }\end{array}$ & Alternatif & $\begin{array}{c}\text { Nilai } \\
\text { Preferensi }\end{array}$ & Keterangan \\
\hline A2 & Kompos & 5 & Rangking 1 \\
\hline A1 & Urea & 4,44 & Rangking 2 \\
\hline A7 & ZA & 4,44 & Rangking 3 \\
\hline A6 & NPK & 4,13 & Rangking 4 \\
\hline A3 & TSP & 3,31 & Rangking 5 \\
\hline A4 & KCL & 2,06 & Rangking 6 \\
\hline A5 & Gandasil & 2,25 & Rangking 7 \\
\hline \multicolumn{3}{|l}{}
\end{tabular}

\section{Perhitungan Metode WP}

Pada saat observasi data telah diberikan bobot awal dalam pemilihan pupuk terbaik sebagai berikut :

Bobot awal atau $\mathrm{W}=[5,4,4,3]$

1. Perbaikan Nilai Bobot

Adapun rumus perbaikan bobot dalam metode WP adalah sebagai berikut :

$W j=\frac{w j}{\sum w j}$

Keterangan :

$\mathrm{Wj} \quad=$ Bobot

$\sum w j=$ Jumlah semua bobot

Lalu dilakukanlah proses pembobotan.

Untuk Harga :

$\mathrm{W} 1=\frac{5}{5+4+4+9}=\frac{5}{16}=0,3125$

Untuk Kualitas : 
Available online at http://jurnal.goretanpena.com/index.php/JSSR

$\mathrm{W} 2=\frac{4}{5+4+4+9}=\frac{4}{16}=0,25$

Untuk Mudah didapat :

$\mathrm{W} 3=\frac{4}{5+4+4+9}=\frac{4}{16}=0,25$

Untuk Bentuk pupuk :

$\mathrm{W} 4=\frac{3}{5+4+4+9}=\frac{3}{16}=0,1875$

Tabel 7. Nilai Bobot Kriteria WP

\begin{tabular}{|c|c|c|}
\hline No & Nama Kriteria & Bobot \\
\hline 1 & Harga & 0,3125 \\
\hline 2 & Kualitas & 0,25 \\
\hline 3 & Mudah Didapat & 0,25 \\
\hline 4 & Bentuk Pupuk & 0,1875 \\
\hline \multicolumn{2}{|c|}{ Jumlah } & 1 \\
\hline
\end{tabular}

2. Menghitung nilai vector

Lakukan tahapan menghitung vector $S$ yaitu nilai dari setiap alternatif. Perhitungan ini dilakukan dengan mengalikan seluruh atribut (kriteria) bagi sebuah alternatif dengan $W$ (bobot) sebagai pangkat positif untuk atribut keuntungan dan bobot berpangkat negatif untuk atribut biaya. Pada kasus ini pemilihan pupuk ini, $W$ (bobot) adalah pangkat positif karena tidak ada atribut biaya (atribut yang nilainya semakin besar semakin merugikan). Berikut adalah cara menghitung vector $S$ dengan rumus sebagai berikut :

$$
S_{i}=\prod_{j=1}^{n} X_{i j} W_{j}
$$

$\mathrm{S} 1=\left(4^{0,3125}\right)\left(4^{0,25}\right)\left(5^{0,25}\right)\left(5^{0,1875}\right)=4,41$

$\mathrm{S} 2=\left(5^{0,3125}\right)\left(5^{0,25}\right)\left(5^{0,25}\right)\left(5^{0,1875}\right)=5$

$\mathrm{S} 3=\left(2^{0,3125}\right)\left(4^{0,25}\right)\left(3^{0,25}\right)\left(5^{0,1875}\right)=3,13$

$\mathrm{S} 4=\left(2^{0,3125}\right)\left(3^{0,25}\right)\left(3^{0,25}\right)\left(5^{0,1875}\right)=2,91$

$\mathrm{S} 5=\left(1^{0,3125}\right)\left(4^{0,25}\right)\left(3^{0,25}\right)\left(1^{0,1875}\right)=1,86$

S6 $=\left(3^{0,3125}\right)\left(4^{0,25}\right)\left(5^{0,25}\right)\left(5^{0,1875}\right)=4,03$

S7 $=\left(4^{0,3125}\right)\left(4^{0,25}\right)\left(5^{0,25}\right)\left(5^{0,1875}\right)=4,41$

3. Menghitung nilai preferensi

Setelah mendapatkan nilai vecto $S$, selanjutnya menentukan perangkingan alternatif dengan cara membagi nilai $\mathrm{V}$ (nilai vector yang digunakan untuk perangkingan) bagi setiap alternatif dengan nilai total dari semua nilai alternatif (vector $S$ ). Perhitungan perangkingan dengan menggunakan rumus sebagai berikut :

$$
V_{i}=\frac{s i}{\prod_{j=1}^{n}\left(x_{j}\right) w j}
$$

Alternatif 1

$$
\begin{aligned}
\mathrm{V} 1 & =\frac{4,41}{4,41+5+3,13+2,91+1,86+4,03+4,41} \\
& =\frac{4,41}{25,75}=0,17
\end{aligned}
$$

Alternatif 2

$$
\begin{aligned}
\mathrm{V} 2 & =\frac{5}{4,41+5+3,13+2,91+1,86+4,03+4,41} \\
& =\frac{5}{25,75}=0,19
\end{aligned}
$$

Alternatif 3

$$
\begin{aligned}
\text { V3 } & =\frac{3,13}{4,41+5+3,13+2,91+1,86+4,03+4,41} \\
& =\frac{3,13}{25,75}=0,12
\end{aligned}
$$

Alternatif 4

$$
\begin{aligned}
\mathrm{V} 4 & =\frac{2,91}{4,41+5+3,13+2,91+1,86+4,03+4,41} \\
& =\frac{2,91}{25,75}=0,11
\end{aligned}
$$

Alternatif 5

$$
\begin{aligned}
\text { V5 } & =\frac{1,86}{4,41+5+3,13+2,91+1,86+4,03+4,41} \\
& =\frac{1,86}{25,75}=0,07
\end{aligned}
$$

Alternatif 6

$$
\begin{aligned}
\text { V6 } & =\frac{4,03}{4,41+5+3,13+2,91+1,86+4,03+4,41} \\
& =\frac{4,03}{25,75}=0,16
\end{aligned}
$$

Alternatif 7

$$
\begin{aligned}
\mathrm{V} 7 & =\frac{4,41}{4,41+5+3,13+2,91+1,86+4,03+4,41} \\
& =\frac{4,41}{25,75}=0,17
\end{aligned}
$$

Dari hasil perhitungan yang

dilakukan berdasarkan metode WP

didapat nilai dari setiap alternatif sebagai berikut :

Tabel 8. Hasil Peringkat Alternatif Pupuk

\begin{tabular}{|c|c|c|}
\hline Peringkat & Alternatif & Hasil \\
\hline 1 & Kompos & 0,19 \\
\hline 2 & Urea & 0,17 \\
\hline 3 & ZA & 0,17 \\
\hline 4 & NPK & 0,16 \\
\hline 5 & TSP & 0,12 \\
\hline 6 & KCL & 0,11 \\
\hline 7 & Gandasil & 0,07 \\
\hline
\end{tabular}

Dari hasil perhitungan metode WSM dan WP dalam penentuan pupuk terbaik didapatkanlah perhitungan dengan hasil yang berbeda. Pada metode WSM Pupuk yang terpilih adalah Pupuk Kompos dengan nilai 5 dan perhitungan pada metode WP Pupuk yang terpilih adalah Pupuk Kompos dengan nilai 0,21. Dengan 
Available online at http://jurnal.goretanpena.com/index.php/JSSR

data yang sama didapatkan hasil perbandingan metode WSM dan WP yang menghasilkan keputusan yang sama tetapi dengan nilai hasil yang berbeda.

\section{SIMPULAN}

Setelah dilakukan penelitian dan pengujian maka kesimpulan yang didapatkan dari perbandingan Metode Weighted Sum Model Dan Metode Weight Product Dalam Menentukan The Best Firtilizer dengan melakukan pendekatan Wsm-Score Dan Vector adalah sebagai berikut: Berdasarkan hasil penelitian yang telah dilakukan sebelumnya, dalam menganalisa jenis-jenis pupuk yang baik pada tanaman dapat dilakukan dengan melakukan observasi langsung kelapangan untuk mendapatkan hasil

\section{DAFTAR PUSTAKA}

Amalia, V., Syamsuar, D., \& Atika, L. (2019). Komparasi Metode Wp Saw Dan Waspas Dalam Penentuan Penerima Beasiswa Pmdk. Jurnal Bina Komputer, 1(2), 122-132. https://doi.org/10.33557/binakom puter.v1i2.452

Fajarianto, O., Iqbal, M., \& Cahya, J. T. (2017). Sistem Penunjang Keputusan Seleksi Penerimaan Karyawan Dengan Metode Weighted Product. Jurnal Sisfotek Global, 7(1), 49-55.

Friskila Parhusip, Dedy Hartama, Z. M. N. (2018). Penerapan metode wsm pada faktor penyebab rendahnya minat mahasiswa dalam belajar bahasa inggris (Vol. 2).

Handoko, D., Mesran, M., Nasution, S. D., Yuhandri, Y., \& Nurdiyanto, H. (2017). Application Of Weight Sum Model (WSM) In Determining
Special Allocation Funds

Recipients. The IJICS

(International Journal of

Informatics and Computer

Science), 1(2), 31-35.

http://ejurnal.stmik-

budidarma.ac.id/index.php/ijics/a rticle/view/528

Luh Made Yulyantari, I. P. W. A. (2018). MANAJEMEN MODEL PADA SISTEM PENDUKUNG KEPUTUSAN.

Mulawarman, J. I., Nurjannah, N., Arifin, Z., \& Khairina, D. M. (2015). Sepeda Motor Dengan Metode Weighted Product. 10(2), 2-6.

Nasyuha, A. H. (2019a). Sistem Pendukung Keputusan Menentukan Pemberian Pinjaman Modal dengan Metode Multi Attribute Utility Theory. JURNAL MEDIA INFORMATIKA BUDIDARMA, $3(2)$.

https://doi.org/10.30865/mib.v3i2 .1093

Nasyuha, A. H. (2019b). Sistem Pendukung Keputusan Menentukan Pemberian Pinjaman Modal dengan Metode Multi Attribute Utility Theory. JURNAL MEDIA INFORMATIKA BUDIDARMA, $3(2)$.

https://doi.org/10.30865/mib.v3i2 .1093

Novita, R., \& Sari, N. (2015). Sistem Informasi Penjualan Pupuk Berbasis E-Commerce. Teknoif, 3(2), 1-6.

Panjaitan, S. M., Manik, S. O., \& Fau, A. (2019). Sistem Pendukung Keputusan Dengan Menerapkan Metode WASPAS Untuk Menentukan Guru Bidang 
Available online at http://jurnal.goretanpena.com/index.php/JSSR

Kesiswaan. 614-619.

Sianturi, L. T. (2019). Implementation of Weight Sum Model ( WSM ) in the Selection of Football Athletes. International Journal of Informatics and Computer Science (The IJICS), 3(1), 24-27. Sugiartawan, P., Rowa, H., \& Hidayat, N. (2018). Sistem Pendukung Keputusan Kenaikan Jabatan Menggunakan Metode Profile Matching. Jurnal Sistem Informasi Dan Komputer Terapan Indonesia (JSIKTI), 1(2), 97-108. https://doi.org/10.33173/jsikti.19
Widia, I. W., \& A., I. G. N. A. (2017). AGROTECHNO Pengembangan Sistem E-Monev Penyaluran Pupuk Bersubsidi di Tingkat Kabupaten The Development of E-Money of Subsidized Fertilizer Distribution At Regency Level 1. 2(1), 161-174.

Zulfandi, A., Anggara, D., \& Handayani, L. (2018). Sistem Pendukung Keputusan Pemilihan Komisaris Kelas Menggunakan Metode Waspas ( Studi Kasus: TI-M1501 STMIK Budi Darma Medan ). 546-551. 